\title{
A FUNÇÃO SOCIOAMBIENTAL DA PROPRIEDADE E O DESENVOLVIMENTO SUSTENTÁVEL
}

\author{
Magno Federici GOMES ${ }^{1}$
}

Wallace Douglas da Silva PINTO

\begin{abstract}
${ }^{1}$ Pós-doutor em Direito Público e Educação pela Universidade Nova de Lisboa-Portugal. Pós-doutor em Direito Civil e Processual Civil, Doutor em Direito e Mestre em Direito Processual, pela Universidad de Deusto-Espanha. Mestre em Educação pela PUC Minas. Professor do Mestrado Acadêmico em Direito Ambiental e Sustentabilidade na Escola Superior Dom Helder Câmara. Professor Adjunto da PUC Minas e Professor Titular da Faculdade de Direito Arnaldo Janssen. Advogado Sócio do Escritório Raffaele \& Federici Advocacia Associada. federici@ pucminas.br

${ }^{2}$ Graduado em Ciências Econômicas pela Pontifícia Universidade Católica de Minas Gerais. Pós-Graduado em Finanças e Controladoria pelo IEC - Instituto de Educação Continuada da Pontifícia Universidade Católica de Minas Gerais. Graduado em Direito pela Pontifícia Universidade Católica de Minas Gerais. Advogado Sócio do Escritório Souza \& Pinto Advogados Associados. wallace@ souzaepinto.com.br
\end{abstract}

\section{Recebido em: 05/03/2015 - Aprovado em: 15/08/2015 - Disponibilizado em: 30/10/2015}

\begin{abstract}
RESUMO: O presente trabalho, por meio do estudo de diversos doutrinadores e com base em suas observações e definições sobre o direito de propriedade e sua função social, bem como seus impactos no meio ambiente, tenta demonstrar o quão difícil é chegar a um significado preciso destes termos, convergindo para a ideia principal de que não há como serem definidos precisamente. Estes institutos são dinâmicos e se modificam a depender do período histórico e da complexidade social ao qual estão inseridos. Fatores como o tipo de colonização e os valores adotados por cada nação levarão fatalmente a diferentes interpretações e, conforme o objetivo histórico almejado, a função social limitará o uso da propriedade de forma a proteger tais pretensões. Fica claro, ainda, que a propriedade privada, desenvolvimento urbano e crescimento populacional geram impactos no meio ambiente, mas não há como impedir tal evolução. Ao contrário, deve-se aliar crescimento com responsabilidade ambiental de forma a minimizar os impactos que virão a ser sentidos e, portanto, gerando condições para que se possa ter um desenvolvimento sustentável, assegurando o direito à vida das futuras gerações.
\end{abstract}

Palavras-chave: Propriedade privada. Função social. Limites históricos. Meio ambiente. Desenvolvimento sustentável.

\section{THE ENVIRONMENTAL FUNCTION OF PROPERTY AND SUSTAINABLE DEVELOPMENT}

\begin{abstract}
This work through studies of several authors and based on their observations and settings where they study the rigth of ownership and its social function, and their impact on the environment, tries to show how difficult it is to reach a precise meaning of these words, converging to the main idea that there is no way to be defined precisely, because the institutes are dynamic and change depending the historical period and social complexity to which they belong. Factors such as the type of colonization values adopted by each nation inevitably lead to different interpretations depending on where the goal one wants, the social function will limit the use of property in order to protect these values. It is clear that private property, urban development and population growth generate impacts on the environment, but there is no stop their growth, in contrast, must combine growth with environmental responsibility to minimize the impacts that will be felt and therefore, developing conditions to achieve sustainable development.

Keywords: Private property. Social function. Historical limits. Environment. Sustainable development.
\end{abstract}

SUMÁRIO: 1 A evolução do direito de propriedade. 2 Os efeitos da distribuição de renda e da colonização brasileira no direito de propriedade. 3 A função social da propriedade e as limitações ao direito de propriedade. $4 \mathrm{O}$ desenvolvimento dos centros urbanos, da propriedade privada e os impactos ao meio ambiente. 5 Considerações finais. Referências. 


\section{A EVOLUÇÃo do DIREITO DE PROPRIEDADE}

Mesmo após séculos de estudo ainda não se conseguiu dar um conceito que seja definitivo a esse tema. Talvez por estar inserido como um direito fundamental do homem e figurar no mesmo patamar de direitos como liberdade, honra e a vida ou mesmo porque para se pensar em direito de propriedade, e consequentemente em seu conceito, não se pode deixar de ter em mente o período e a sociedade na qual se analisa o referido instituto. $\mathrm{O}$ direito de propriedade por estar intimamente ligado à evolução social e ao convívio humano a cada período da história recebe uma interpretação que certamente é única para aquele momento e será completamente diferente quando analisado em outra ocasião.

Nesse sentido, leciona Maluf (2010) sobre o quão difícil é traçar a definição de seu significado com clareza e precisão:

Apesar de a propriedade ser o instituto que menos se modificou, dentro do direito civil, desde o direito romano, jamais se pode, em tempo algum, efetivamente defini-la com clareza e precisão. Pelo contrário, tais conceitos estiveram e ainda estão em plena fase de mutação e adaptação, de acordo com os valores econômicos, políticos, religiosos, sociais de cada época ${ }^{1}$.

\footnotetext{
1 MALUF, Adriana Caldas do Rego Freitas Dabus. Limitações ao direito de propriedade. São Paulo: Atlas, 2010, p. 05.
}

Em tempos primitivos, onde não havia uma sociedade organizada e os homens dessa época tinham uma vida tal qual a dos animais, sobrevivendo da caça e pesca e sem residência fixa, conforme afirma Zea $\left(1973^{2}\right)$, não havia nenhuma classe de propriedade, não deixando dúvida, portanto, que o momento histórico e as evoluções do período vão levar a diferentes entendimentos. Nessa mesma linha de raciocínio, Tigar e Levy (1978) ao analisarem a concepção de John Locke sobre as ideias do estado de natureza, concluem que "a propriedade era uma instituição humana justificada pelo direito natural", ${ }^{, 3}$ sendo para eles assim explicada:

\begin{abstract}
No estado de natureza, o homem penetrava na floresta e começava a plantar. Misturava seu trabalho com a terra e produzia uma colheita. Outro abatia um cervo e combinava seu trabalho com a carne e o couro para fazer alimentos e vestuário. Os dois, graças a seu trabalho, criavam valores que não haviam existido antes e, por conseguinte, tinham direito natural a seu produto. $\mathrm{O}$ que poderia ser mais naturalmente certo do que eles negociarem suas propriedades como iguais? ${ }^{4}$.
\end{abstract}

O pensamento acima demonstra como a cooperação econômica funciona como fonte dos bens patrimoniais, mas, na visão de Coulanges (2000), essa não é a única fonte. Tem-se que:

\footnotetext{
2 ZEA, Arturo Valenciano. Derecho civil. 4. ed. Bogotá: Temis, 1973, p. 144-145.

3 TIGAR, M.; Levy M. $O$ direito e a ascensão do capitalismo. Rio de Janeiro: Zahar Editores, 1978, p. 286.

${ }^{4}$ TIGAR, M.; Levy M. $O$ direito e a ascensão do capitalismo - ob. cit., 1978, p. 286.
} 
quando se constrói o lar, é com pensamento e a esperança de que continue sempre no mesmo lugar. $\mathrm{O}$ deus ali se instala, não por um dia, nem pelo espaço de uma vida, mas por todo o tempo em que dure essa família e enquanto restar alguém que alimente a chama do sacrifício. Assim o lar toma a posse da terra; essa parte da terra torna-se sua, é sua propriedade ${ }^{5}$.

Para Coulanges ${ }^{6}$, a propriedade tem o seu nascedouro fundado na construção da família e da religião e ao se agrupar em torno de um deus familiar o homem acabava por delimitar o espaço onde poderia cultivar a terra e retirar dela o necessário ao seu sustento, mas principalmente acabar com a vida nômade de seus antepassados. A essa altura já existia a ideia de que esse espaço onde se cultivava, se cultuava os deuses e matinha um lar, dava-lhe a posse sobre essa terra, que passava a ser sua propriedade. A fixação de um lar e a convivência em sociedade trouxe consigo a necessidade de cooperação entre seus membros, visando principalmente a sobrevivência, o que, segundo Maluf (2010), pode ter levado ao surgimento das primeiras comunidades compostas por famílias com alguma organização, como, por exemplo, a divisão de trabalho.

As complexas relações de convívio em comunidade, de início vista por Coulanges ${ }^{7}$

5 COULANGES, Fustel de. A cidade antiga. São Paulo: Martins Fontes, 2000, p. 94.

${ }^{6}$ COULANGES, Fustel de. A cidade antiga - ob. cit., 2000, p. 94.

${ }^{7}$ COULANGES, Fustel de. A cidade antiga - ob. cit., 2000, p. 94. como fundada nas divindades domésticas, segundo as quais os deuses determinavam o vínculo entre a família e o solo, sua propriedade particular e sua terra privada, na visão de Maluf (2010), desempenham importante papel na estrutura social que se formava com a fixação do homem à terra. Para a autora (2010), esse fato deve-se ao desenvolvimento cerebral dos homens:

O homem encontrava-se
misticamente ligado aos membros de
seu clã, a este pertencendo o conjunto
de objetos extracorpóreos que
compõem a sua individualidade, ou
seja, toda a forma de propriedade
conhecida nessa época é coletiva,
pertence ao grupo, ao clã. O solo, por
sua vez, é considerado sagrado,
divinizado representando a sede das
forças naturais.
Com o passar das eras e com o
consequente desenvolvimento
cerebral dos homens, estes passaram
a desenvolver a agricultura e a
pecuária, aprimorando os meios de
produção, tornando-se sedentários, ou
seja, estabeleceram-se num
determinado pedaço de terra de forma
definitiva, formando, assim, as
primeiras aldeias 8

$\mathrm{Na}$ visão de Maluf (2010), a propriedade evoluiu passando por regimes sendo o primeiro deles o romano, que efetivamente havia desenvolvido a propriedade a partir da fixação na terra. Esse período é marcado, segundo a autora (2010), pela primeira manifestação concreta de propriedade, ou seja:

\footnotetext{
8 MALUF, Adriana Caldas do Rego Freitas Dabus. Limitações ao direito de propriedade - ob. cit., 2010, p. 10.
} 
A primeira manifestação concreta de propriedade de que se tem notícia foi o heredium, lote de terra atribuído a cada chefe de família com meio hectare de extensão, que trazia gravado em si um caráter de hereditariedade. Inicialmente destinada aos patrícios, foi também, a partir da Lei das XII Tábuas, estendida aos plebeus a possibilidade de sua aquisição 9 .

Para Alvim $\left(1980^{10}\right)$, o direito romano classificava a história em três fases, a saber: direito antigo, direito clássico e o direito pósclássico, sendo cada qual marcada por um tipo de propriedade a ela inerente e que tinham características peculiares. No direito antigo, existia apenas a propriedade quiritária, de domínio restrito ao espaço geográfico de Roma, cujo proprietário era um cidadão de Roma e seu modo de transmissão dava-se quando inter vivos, pelo modo de aquisição do ius civile, não sendo admitida outra além dessa que não fosse a usucapião. A partir do período clássico, a propriedade quiritária coexistia com novos tipos, a bonitária, a provincial e a peregrina.

Esse período da história romana foi marcado pelo poder absoluto que o proprietário poderia exercer sobre a propriedade. Nas palavras de Scialoja (1933):

definia-se o domínio da propriedade romana como o poder máximo de uso

\footnotetext{
9 MALUF, Adriana Caldas do Rego Freitas Dabus. Limitações ao direito de propriedade - ob. cit., 2010, p. 16.

10 ALVIM, Rui Carlos Machado. Análise das concepções romanas da propriedade e das obrigações: reflexos no mundo moderno. Revista de Direito Civil, Imobiliário, Agrário e Empresarial, São Paulo, ano 4, v. 12 , p. $25-38$, abr./jun. 1980 , p. 32.
}

da coisa, que detinha o seu proprietário, de dispor, de aliená-la, de gravá-la, de reivindicá-la e por fim de destruí-la, se assim lhe aprouvesse, não obstante ser esta uma característica negativa. Ou seja, era retirada qualquer ingerência de terceiros sobre a coisa, que a final pertencia ao seu legítimo proprietário. Assim, a propriedade veio denominada como absoluta, geral, independente, plena, universal, ilimitada e exclusiva. Cada uma das faculdades do domínio foi denominada jus utendi, fruende et abutendi $i^{11}$.

Quanto ao período medieval, marcado pela propriedade feudal, tem-se que o domínio fundiário era a fonte de poder. Havia de um lado o poder direto sobre a terra que pertencia ao senhor feudal, suserano, e o utile, pertencente ao vassalo, obrigado ao pagamento de dízimos e prestação de serviços militares. Esquematicamente, o período era marcado por um poder de soberania do senhor feudal que tinha sob sua guarda pequenos proprietários de terra, os vassalos, que recebiam a transmissão do gozo e fruição dela. A propriedade feudal tinha como característica ser um direito vitalício, intransmissível, inalienável e hereditário.

É claro que a sociedade ainda embrionária e a convivência entre seus integrantes seria fortemente influenciada por esse poderio absoluto sobre a propriedade e, muito embora houvesse essa concepção extremista de poder sobre a propriedade, deveria haver limitações a serem impostas

\footnotetext{
${ }^{11}$ SCIALOJA, Vittorio. Teoria della proprieta, lezioni ordinate, curate. Roma: Edite da Pietro Bonfante, 1933. v. II, p. 19.
} 
pela lei com o objetivo de fornecer condições para o uso do domínio e valorizar a convivência social. Tais limitações eram divididas juridicamente em obrigações de não fazer ou tolerar.

Além do poder absoluto sobre a propriedade, o período feudal foi também marcado pela exploração do mais fraco ${ }^{12}$. Eram os camponeses que representavam a maioria da população e mantinham a sociedade por meio de seu trabalho de cultivo da terra e pagamento de impostos por sua utilização. Essa pressão dos senhores feudais sobre a massa menos favorecida da população fez com que surgissem reações das ordens religiosas, colocando-se contra a violência e o acúmulo de riquezas. Maluf (2010) afirma que a Igreja, sob a influência de Santo Agostinho e Santo Tomás de Aquino, entendia a propriedade como sendo um direito individual e sagrado, mas que acima de tudo deveria ser exercido em benefício de todos, momento em que começou a dar relevo à função social da propriedade. Nesse contexto, afirma a autora (2010) que:

No final do século XIX, a encíclica Rerum Novarum (de 15.5.891) veio retomar os ensinamentos de Santo Tomás de Aquino "pregando a necessidade de que a propriedade individual, embora devesse ser respeitada e sendo mesmo necessária e decorrente do direito natural, deveria ser sempre empregada com a finalidade de atender aos interesses de todos, e não apenas aos do proprietário, devendo o excedente destinado às necessidades individuais

\footnotetext{
${ }^{12}$ Leia-se os camponeses.
}

do proprietário, ser colocado para o atendimento do interesse geral ${ }^{13}$.

Nesse período, a necessidade de fortificações e diversas outras ações empreendidas com intuito de dar proteção aos grupos sociais deram origem a expropriação de bens particulares por necessidade pública com o pagamento de indenização, conforme Maluf $\left(2010^{14}\right)$ e denotam que as restrições ao direito de propriedade vêm aumentando com o passar do tempo. Tal fato remete ao que já foi dito acerca da evolução das relações sociais, as quais impulsionam uma evolução do conceito de propriedade e que geraram uma necessidade cada vez maior de se impor limitações ao seu uso, em prol dos interesses sociais e coletivos.

Com a Revolução Industrial surgiu o direito moderno, período no qual a propriedade sofreu suas maiores transformações em razão do aparecimento de grandes latifúndios e do nascimento do mercantilismo, sistema que pregava o dinheiro ou metal precioso como a verdadeira riqueza. O direito de propriedade está disposto na Declaração dos Direitos do Homem como inviolável e sagrado, situado no mesmo nível que a liberdade, e foi esculpido em seu art. $2^{\circ}$, donde se retira que ninguém pode ser privado da propriedade a

\footnotetext{
${ }^{13}$ MALUF, Adriana Caldas do Rego Freitas Dabus. Limitações ao direito de propriedade - ob. cit., 2010, p. 25 .

14 MALUF, Adriana Caldas do Rego Freitas Dabus. Limitações ao direito de propriedade - ob. cit., 2010, p. 26.
} 
não ser por necessidade pública e mediante justa indenização.

A dicotomia de ideias após a Revolução Francesa, onde de um lado restavam os defensores da propriedade privada e de outros aqueles que ainda cultuavam a propriedade comum, em meio a um emaranhado de novas ideias que surgiam a cada dia e que em sua maioria ainda não estavam alicerçadas, fez com que Napoleão, com receio de retorno ao modo da propriedade típica do sistema feudal, privilegiasse em seu código o caráter absoluto do direito de propriedade.

Enfim, chega-se ao período moderno ainda sem ter uma definição precisa para $o$ significado do direito de propriedade. Confirma-se o pensamento inicial de que não há definição possível para esse instituto senão aquelas feitas com observância do período histórico e valores sociais em que tal definição esteja inserida. Ao convergir nessa linha de pensamento, Maluf $\left(2010^{15}\right)$ afirma que a evolução da sociedade e da economia mostra um retrocesso da qualidade frente à quantidade da propriedade imobiliária, na medida em que essas mudanças dão margem ao surgimento de novas propriedades, como as incorpóreas, como exemplo a propriedade intelectual. Aponta Pereira (1993) que:

ao chegar-se no limiar da Idade Moderna do direito, não é por mero

\footnotetext{
15 MALUF, Adriana Caldas do Rego Freitas Dabus. Limitações ao direito de propriedade - ob. cit., 2010, p. 28.
}

acaso que outra concepção de propriedade se emoldura, diversa da que vigora por um milênio de civilização. Novas ideias políticas se elaboram. Verifica-se a impossibilidade de conservar-se o conceito da propriedade estranho à configuração das ideias liberais, da noção de liberdade, da tendência individualista, no momento em que o panorama político se transforma, com ele se metamorfoseia a propriedade ${ }^{16}$.

Portanto, depreende-se que a propriedade terá sua definição esculpida pelo momento histórico em análise, valores que a regem e pela evolução que cada sociedade ou país apresenta. Uma breve análise comparativa da propriedade em diferentes países, como mostrado no estudo de Maluf (2010), revela que os limites que se dá à propriedade para que possa atingir o objetivo pretendido pela função social são distintos, pois cada nação determina os valores que acha mais importante assegurar. Países da Europa valorizam fortemente o seu acervo histórico e cultural. Desta forma, as limitações impostas à propriedade certamente terão diversas diretrizes voltadas à proteção deste patrimônio.

\footnotetext{
16 PEREIRA, Caio Mário da Silva. Condomínio $e$ incorporações. 7. ed. Rio de Janeiro: Forense, 1993, p. 27.
} 
2 OS EFEITOS DA DISTRIBUIÇÃO DE

RENDA E DA COLONIZAÇÃO

BRASILEIRA NO DIREITO DE

PROPRIEDADE

Muito embora o descobrimento do Brasil tenha se dado em 1500, somente após 30 anos teve início, de fato, a colonização de suas terras. Nesse período ficaram os portugueses adstritos ao campo das expedições para reconhecimento e como se sabe extração de pau-brasil.

Nessa época, período em que além de Portugal, Espanha, Inglaterra e Holanda percorriam os mares à procura de terras, gerou nos portugueses o temor de que as recémdescobertas terras pudessem ser invadidas por um desses países, fazendo então com que em 1530 chegasse ao Brasil a primeira expedição colonizadora, chefiada por Martim Afonso de Souza, para iniciar a implantação dos povoamentos no litoral e o processo exploratório em busca de metais preciosos, bem como, ao mesmo tempo, proteger o território de possíveis invasores.

Por óbvio, para alcançar seus objetivos, Portugal teria que enviar para o Brasil pessoas dispostas a morar em um lugar longe de qualquer espécie de condição de vida, que tinha em sua terra natal. Ademais, seria necessário o pagamento de grandes valores, além de concessão de grandes extensões de terras, para motivar a vinda para o inóspito território. Essas grandes massas de terras eram entregues aos desbravadores portugueses via Capitanias Hereditárias e concessões de Sesmarias, dando início à formação da propriedade privada brasileira.

Os territórios, inicialmente de domínio público ante a necessidade de proteção, exploração e colonização, foram se transferindo à propriedade privada por meio dos institutos citados e, por conseguinte, via comercialização, legitimação de posse e permutas, seguindo a regra de que toda a propriedade particular sem título legal era pública ou devoluta.

Leciona Maluf (2010), sobre a origem da propriedade territorial no Brasil, que:

repousou nas concessões públicas e
no reconhecimento da ocupação
primária das terras como forma de
consolidação e formulação da
dominialidade de tal como hoje é
entendida. Desta sorte, a constatação
historicamente determinada é que a
propriedade no Brasil originou-se
fundamentalmente do patrimônio
público ${ }^{17}$.

Com os colonos fixados à terra tem-se o início da cultura de cana-de-açúcar, monocultura que exige grandes extensões territoriais para o plantio, estando toda a produção da época voltada para o mercado exportador. Essa fase da colonização brasileira deu início à formação das propriedades no Brasil. Portugal concedia aos donatários a terra sem, contudo, lhes conceder

\footnotetext{
17 MALUF, Adriana Caldas do Rego Freitas Dabus. Limitações ao direito de propriedade - ob. cit., 2010, p. 29.
} 
a emissão de propriedade. Desta forma, mantinha para si o seu domínio, sendo ao donatário permitido o direito de conceder Sesmarias, isto é, explorar e produzir nas terras. Essa medida inicial, que tinha o intuito de garantir o novo território seguro e também estimular a exploração, caracterizava-se principalmente por manter as terras sob o domínio de Portugal que podia retomar e transferir a posse em casos de descumprimento das condições legais impostas, tornando o processo de concessão de terras amplamente privilegiado.

Com o fim das Sesmarias em 1822 e até 1850 e com a Lei das Terras Devolutas, houve um vácuo jurídico que permitiu o surgimento de um período chamado "Império das Posses", em que, por não haver nenhuma espécie de regulamentação de terras, tinha-se a posse como a única forma de aquisição, dando margem para o aumento de posseiros e a formação de grandes propriedades. Com a proclamação da Independência do Brasil surgiu a necessidade de uma sistemática que definisse a propriedade territorial que foi cumprida pela Lei $\mathrm{n}^{\circ} 601$, de 18 de setembro de 1850, Estatuto das Terras Devolutas, que favoreceu a livre penetração e povoamento da colônia.

É notório que a sistemática utilizada pela Coroa portuguesa na colonização brasileira, resultou em grandes quantidades de terras nas mãos de poucos privilegiados devido ao favorecimento por interesses do colonizador. Esse período é marcado pela visão de que a riqueza é medida pela quantidade de terras que se possui, o que, em princípio, desnatura o sentido da propriedade privada e implicou em uma relação equivocada de que a propriedade privada é um direito dos ricos. Ressalta-se que o acúmulo de terras na mão de uma minoria, escolhida com base em critérios de "preferência" pelo colonizador sedimentou o paradigma de que existe um privilégio legal no Brasil de uma minoria em detrimento da maioria.

Importante destacar que a dinâmica de colonização pautada em fins exploratórios, sem qualquer preocupação com a delimitação e distribuição das terras no recém-descoberto território, estigmatizou a ideia de que no Brasil a propriedade é um mal, pois somente os ricos a possuem, esquecendo-se de que no caso da propriedade privada também pode-se auferir benefícios para o bem coletivo, tais como aumento dos postos de emprego que tem como consequência uma melhor condição de vida.

Esse pré-julgamento de que a propriedade no Brasil é elitizada e destina-se a poucos abastados, devido a favorecimentos ou riqueza, aliado à realidade de uma nação onde a grande massa da população encontrase abaixo da linha da pobreza, trás grandes entraves à propriedade privada, posto que, como dito, esquece seu importante papel na medida em que cumprindo a sua função social 
trará benefícios para todos indiferentemente de seu nível social.

Em um país onde $10 \%$ da população concentra quase metade de toda a riqueza nacional, fica muito difícil a discussão sobre a propriedade privada, uma vez que ela evoluiu em meio a uma visão negativa de ser um direito quase inalcançável e que os governantes tem a obrigação legal ou constitucional de entregá-la a todos. A falta de políticas públicas e de planejamento urbano gera uma tendência à favelização e degradação do meio ambiente, pois à medida em que há um êxodo do meio rural para o urbano, na busca de melhores condições de vida, esses migrantes, por não terem onde se alocar, começam a se agrupar em vilas que vão formando bolsões à margem da sociedade urbana, na qual vigora invariavelmente o crime e a violação de direitos. Como assevera Rosenfield (2008):

\footnotetext{
Historicamente, o direito de propriedade é precariamente assegurado entre nós. Isto vale tanto para as favelas - que constituem, num certo sentido, um mundo à parte, regido por normas que não se adéquam totalmente ao sistema legal de propriedade -, quanto nas invasões de terras no campo passando pelo desrespeito aos contratos. É como se o contrato entre os particulares só devesse ser respeitado sob certas condições que nem as partes sabem exatamente quais são. Em outras ocasiões, eles podem ser cabalmente menosprezados por ações coletivas que procuram enfraquecer a propriedade privada com o intuito de eliminá-la. Pense-se, ainda, no sequestro da poupança privada no governo Collor, quando essa forma de propriedade foi flagrantemente
}

afrontada. Atualmente, observamos uma desconsideração com as Agências Reguladoras, o que implica também num desrespeito aos contratos assinados, afugentando novos investidores pela insegurança produzida $^{18}$.

Se ao invés de ignorar as favelas, deixadas à margem do direito, tendo sua dignidade humana desrespeitada a cada momento, se fizesse uma política a fim de reconhecer nesses locais o direito de propriedade, haveria, como descreve Rosenfield (2008), uma repercussão muito grande nos campos social, econômico e político. Nesse sentido:

Num país como o Brasil, onde milhões de pessoas vivem em situações precárias em relação à posse de moradia, onde esse tipo defectivo de propriedade não é reconhecido pelo sistema legal da sociedade, tornar essas posses precárias propriedade no sentido estrito da palavra seria uma política de ampla repercussão econômica, social e política. Econômica, pois esses indivíduos poderiam empregar sua energia e a sua capacidade de empreendedorismo em um instrumento de capitalização dos seus bens, ingressando, como cidadãos e não como cidadãos de segunda categoria, no mercado. Socialmente, pois esses indivíduos pela valorização dos seus ativos, poderiam melhorar a vida de seus familiares, vindo a gozar de uma melhor condição social. Politicamente, pois se tornariam menos submissos a políticas clientelistas e, mesmo, poderiam se libertar, com a ajuda do aparelho estatal, do crime organizado. Também uma política habitacional, com juros acessíveis e prestações fixas, propiciaria aquisição de moradia própria para os que ainda

18 ROSENFIELD, Denis Lerrer. Reflexões sobre o direito à propriedade. Rio de Janeiro: Editora: Campus Jurídico, 2008, p. 83. 
não a possuem. Haveria tanto a satisfação de uma necessidade básica quanto o desenvolvimento do mercado imobiliário, com mais empregos, renda e salários. Indivíduos proprietários são menos propensos ao clientelismo político, que termina se desenvolvendo pela ausência mesma de direitos ${ }^{19}$.

Percebe-se que a propriedade no Brasil, surge e se desenvolve marcada por influências negativas devidas tanto às origens coloniais quanto à má distribuição de renda brasileira, o que levou a um distoamento da visão que atualmente se tem dela.

A concentração de gigantescas porções de terras nas mãos de poucos, a ideia exclusivista da propriedade decorrente do período colonial e aliando-se a isso o grande número de marginalizados sociais criados pela distribuição desigual de renda, e que não tem condição de adquirir a propriedade, denotam que no Brasil existirá sempre a ideia avessa de que a propriedade privada é um mal social e persistirá o pensamento de que o governo deve intervir de forma a distribuí-la a todos, esquecendo-se que com a propriedade segue uma série de encargos que seu adquirente deverá arcar enquanto dela for proprietário.

\section{A FUNÇÃO SOCIAL DA PROPRIEDADE E AS LIMITAÇÕES AO DIREITO DE PROPRIEDADE}

A própria evolução da propriedade, mostrou que suas características podem ser diferentes e mais complexas de acordo com o período histórico em análise. $\mathrm{Na}$ antiguidade, ela foi marcada por características mais simples; ao contrário, por exemplo, do que se constata na Idade Moderna, quando as próprias relações sociais mais elaboradas conferem à propriedade uma importância muito maior, exercendo grande influência na vida e no cotidiano das pessoas. A esse respeito comenta Fachin (1987):

O processo histórico de apropriação
do homem sobre a terra ocorreu de
modo artificial, de onde advém que
em cada época a propriedade recebeu
contornos diferentes, de acordo com
as relações sociais e econômicas
vigentes. O grau de complexidade
hoje alcançado pelo instituto da
propriedade deriva do grau de
complexidade alcançado pelas
relações sociais ${ }^{20}$.

Durante esse período evolutivo, foi sendo enfraquecida a ideia do caráter absolutista da propriedade e que, conforme leciona Maluf $\left(2010^{21}\right)$, foi resgatada com o Código de Napoleão. Acabou produzindo enormes discussões de juristas e pensadores

20 FACHIN, Luiz Edson. Da propriedade como conceito jurídico. Revista dos Tribunais, São Paulo, v. 76, n 621, p. 16-39, jul. 1987, p. 24.

${ }^{21}$ MALUF, Adriana Caldas do Rego Freitas Dabus. Limitações ao direito de propriedade - ob. cit., 2010, p. 55.

ROSENFIELD, Denis Lerrer. Reflexões
direito à propriedade - ob. cit., 2008, p. 80-81. 
na tentativa de retirar dela esse caráter inviolável e sagrado, devendo-se destacar os posicionamentos de Del Nero (1997) e Giordani (1991). Nota-se que já há uma preocupação com o pensamento de que o direito de propriedade está intrinsecamente ligado à função social da propriedade, além da opinião da Igreja manifestada, via encíclica Rerum novarum, que defendia a concepção de que a propriedade era um direito natural do homem, devendo ser, portanto, defendido por leis sábias. Para Del Nero (1997):

O sentido da expressão função social da propriedade reflete ora uma certa maneira de interpretar $o$ direito positivo ora uma determinada forma de conceber o próprio direito. Devese considerar também a passagem do Estado Liberal do século XIX para o Estado social do século XX, onde o âmago do seu princípio está na limitação dos direitos individuais. $\mathrm{Na}$ responsabilização pela coexistência do bem comum, convivem lado a lado o homem individual e a própria sociedade $^{22}$.

Já nas palavras de Giordani (1991):

Com nenhuma dessas restrições, entretanto, se confunde o princípio da função social da propriedade, esta não surge como mero limite ao exercício do direito de propriedade, mas como princípio básico que incide no conteúdo do direito, fazendo parte de sua estrutura, não devendo-se entretanto chegar ao extremo de classificar a propriedade como mera

\footnotetext{
${ }^{22}$ DEL NERO, João Alberto Schutzer. O significado jurídico da expressão "função social da propriedade". Revista da Faculdade de Direito de São Bernardo do Campo, São Bernardo do Campo, v. 3, p. 79-97, 1997, p. 79. Para melhor entendimento, ler DEL NERO, João Alberto Schutzer. O significado jurídico da expressão "função social da propriedade" - ob. cit., 1997, p. 7981.
}

função. A função social não foi erigida com o escopo de transformar a propriedade em um ônus para o seu titular, mas sim fazer com que ela seja utilizada segundo sua destinação original, e que deve ser aplicada segundo o princípio da razoabilidade ${ }^{23}$.

Não há, portanto, como se pensar em propriedade sem ter como princípio básico de sua existência, a sua função social que, nos dizeres de Maluf $\left(2010^{24}\right)$, são entendidos como o dever e o poder que tem o proprietário do bem de realizar a satisfação das suas necessidades pessoais, visando concomitantemente a satisfação das necessidades comuns da coletividade. O crescimento econômico e a melhora das condições de vida importam no desenvolvimento das antigas comunidades, hoje grandes cidades, e no necessário convívio coletivo que, por sua vez, criam a necessidade de priorização da harmonização de interesses sociais, individuais e os impactos de seu crescimento no meio ambiente.

$\mathrm{Na}$ atual estrutura das sociedades modernas, é impossível manter ou assegurar os direitos coletivos ou individuais de forma que um não afete o do outro, ou seja, se para se preservar um melhor convívio social for necessário uma possível restrição a um direito

\footnotetext{
${ }^{23}$ GIORDANI, Jose Acir Lessa. Propriedade imóvel: seu conceito, sua garantia e sua função social na nova ordem constitucional. Revista dos Tribunais, São Paulo, v. 80, nº 669, p. 47-56, jul. 1991, p. 50.

${ }^{24}$ MALUF, Adriana Caldas do Rego Freitas Dabus. Limitações ao direito de propriedade - ob. cit., 2010, p. 56.
} 
individual, haverá certamente um descontentamento de quem for privado ou restrito daquele direito, mas que se justifica pelo benefício coletivo que irá produzir. Certamente, nesse contexto, os direitos coletivos elevam de patamar, pois devem ser observados em detrimento dos direitos individuais em prol de um ganho social. Nesse sentido, aduz Maluf (2010) que:

Atualmente, entendem a doutrina e a jurisprudência que a propriedade está investida de uma predominante função social, harmonizando o interesse individual e o social, "tendo sido inserida esta como princípio constitucional de ordem econômica fundada na valorização do trabalho livre e na livre iniciativa, com o fito de assegurar a todos a existência digna, conforme os ditames desse princípio em relação a propriedades urbanas e rural" ${ }^{25}$.

A própria função social, segundo Dorneles (2011), tem seu conceito alterado para atender à coletividade. Nesse sentido:

as transformações históricas adaptam a propriedade ao clamor social da sociedade envolvida, ou seja, atualmente, a função social da propriedade foi adaptada historicamente, de forma que as necessidades de cada época foram designando a função a ser atendida pela propriedade privada ${ }^{26}$.

A função social não pode ser concebida de forma restrita, de modo que tem

${ }^{25}$ MALUF, Adriana Caldas do Rego Freitas Dabus. Limitações ao direito de propriedade - ob. cit., 2010, p. 59.

26 DORNELES, Ana Clara Bertoglio. A função socioambiental da propriedade e a propriedade privada. Revista de Direito Ambiental e Sociedade, Caxias do Sul, v. 1, no 1, p. 273-300, jan./jun. 2011, p. 279. se consolidado uma noção mais ampla segundo a qual a propriedade deve cumprir, em verdade, uma função socioambiental. Isso significa que tanto o proprietário, como a sociedade e o Estado devem atuar de forma a preservar o equilíbrio do meio ambiente. $\mathrm{O}$ cumprimento dessa função socioambiental não é exclusivamente a posteriori, pelo contrário, deve se dar de forma a evitar danos ambientais, ou seja, preventivamente. $\mathrm{O}$ descumprimento dessa função implica a adoção de limitações ao exercício do direito de propriedade, como explica Dorneles $\left(2011^{27}\right)$.

É devido a esse novo tipo de convivência social, mais complexa, e de grandes proporções, que a função social produz uma série de condições ao direito de propriedade, de forma a não prejudicar o interesse social. A função social surge então, na verdade, como conjunto de limitações ao direito de propriedade, na medida em que restringe os direitos sobre ela em benefício do bem social. Na visão de Maluf (2010):

Entendemos a função social da
propriedade como o plexo de
limitações ou restrições legais que
regulam o uso da propriedade,
visando coibir o seu mau uso e evitar
o seu individualismo, sem, no
entanto, alterar-lhe a substância,
visando ao bem-estar da coletividade,
valorizando a essência do ser humano

27 DORNELES, Ana Clara Bertoglio. A função socioambiental da propriedade e a propriedade privada - ob. cit., 2011, p. 283. 
e possibilitando a sua sobrevivência com dignidade ${ }^{28}$.

Mais especificamente, surge com o direito moderno várias restrições ao direito de propriedade tais como: lei do inquilinato, parcelamento do solo urbano, lei de zoneamento, servidões, tombamento, desapropriação, relações de vizinhança, condomínio edilício e proteção ao meio ambiente, todas visando a utilização da propriedade de modo racional, razoável e em benefício da coletividade.

No Brasil, devido à ideia de propriedade absoluta, segundo a qual, tendo o direito à propriedade, tem-se também o direito de nesse espaço fazer o que se desejar e ser o senhor absoluto, sem admitir interferências externas ainda que em prol da maioria. Tais limitações são tidas como uma espécie de intromissão do governo em um espaço que somente o dono deveria determinar as próprias diretrizes $^{29}$.

Mas não há espaço no mundo atual para se considerar a propriedade como ilimitada, limites esses que, apesar de restringirem alguns direitos do proprietário, são necessários, pois essas restrições aos direitos individuais foram criadas e existem com o fulcro de trazer harmonia e boa convivência na sociedade moderna.

\footnotetext{
${ }^{28}$ MALUF, Adriana Caldas do Rego Freitas Dabus. Limitações ao direito de propriedade - ob. cit., 2010, p. 61.

${ }^{29}$ Entenda-se fazer o que deseja ou não em seu terreno.
}

As antes simples aglomerações, onde se reuniam os homens em torno de deuses ou famílias, evoluíram e se constituíram em organizadas e complexas sociedades; cujo intuito é satisfazer os interesses e necessidades do indivíduo e conviver harmonicamente com sistemas econômicos, políticos, industriais e ambientais. Para tanto, é indispensável regras específicas para que se consiga tal objetivo.

A propriedade não foge à regra e por ser um importante integrante desse sistema requer limitações para que seja utilizada de forma racional e que traga benefícios a todos os demais integrantes da sociedade. E é com esse objetivo que surge a função social, exercendo um papel limitador do uso da propriedade, mas trazendo à baila um conjunto de regras e imposições cuja finalidade é que sua utilização não traga apenas satisfação individual, mas que gere frutos que beneficiem a todos.

$\mathrm{O}$ crescimento das cidades torna ainda mais complicado o convívio entre seus integrantes. Simultaneamente, os homens se encontram cada vez mais dependentes delas para sua sobrevivência, de tal forma que um não vive sem o outro. Nos dizeres de Goitia (2003):

a própria vida se alberga no seu seio, até o ponto de nos confundir e nos fazer crer que são as cidades que vivem e respiram. Tudo que afeta o homem afeta a cidade, e é por isso que, muitas vezes, o que há de mais recôndito e significativo numa cidade será dito pelos poetas e novelistas. 
Desta forma, homem e cidade no mundo contemporâneo perdem o significado individual para tornaremse um grande corpo complexo, não fragmentado, onde as figuras urbanísticas, conjuntamente, concorrem para a viabilização da vida no espaço urbano ${ }^{30}$.

Com uma relação tão próxima entre o homem e a cidade, regras de convivência no tocante a propriedade passam a ser necessárias e a função social da cidade surge para organizar e regular a propriedade urbana. Essa preocupação com a organização das cidades não veio apenas com o aparecimento das grandes metrópoles, mas, como comenta Maluf (2010), vem de tempos mais remotos:

Pode-se afirmar, entretanto, que a preocupação com a ordenação das cidades não é nova, existindo desde os primeiros núcleos populacionais o respeito ao cidadão e à sua integridade (na França, registros históricos apontam para 1605 a edição de uma abrangente legislação edilícia, que serviu posteriormente de modelo para o mundo todo $)^{31}$.

Diferentemente de outros países, no Brasil a preocupação com o fenômeno urbano surge nos tempos coloniais quando da necessidade de povoamento do território para obtenção de renda e defesa do novo território que, segundo Prado Júnior (1988), se dividia em três fases:

30 GOITIA, Fernando Chueca. Breve história do urbanismo. Tradução por Emílio Campos Lima. 5. ed. Lisboa: Editorial Presença, 2003, p. 09.

${ }^{31}$ MALUF, Adriana Caldas do Rego Freitas Dabus. Limitações ao direito de propriedade - ob. cit., 2010, p. 64-65.
[...] A primeira fase, que se estendeu de 1530 a 1570 , apresentou seu ponto alto na fundação da cidade do Rio de Janeiro em 1567. O segundo período, que se situa de 1580 a 1640, foi marcado pela fundação de vilas e cidades, propiciando uma urbanização sistemática da costa norte em direção à Amazônia. O terceiro período que vai de 1620 a 1650, inclui a fundação de trinta e cinco vilas, e dentre as já existentes, duas foram elevadas à categoria de cidades: Olinda e São Paulo, fundada em 1554; sendo que, no final desse período, a rede urbana brasileira continha um significativo número de sessenta e três vilas e oito cidades ${ }^{32}$.

Essa política de ocupação via interesses das autoridades e a formação de vilas também motivadas pelos diversos ciclos econômicos brasileiros como, por exemplo, cultivo de cana-de-açúcar, ciclo do café e ciclo do ouro, fomentava a busca desenfreada pelas cidades, gerando um inchaço nos núcleos populacionais dos estados de São Paulo, Rio de Janeiro e Minas Gerais. Assim descreve Maluf (2010) que:

Os diversos ciclos econômicos brasileiros propiciaram o aparecimento de cada vez mais vilas e cidades, ampliando-se assim paulatinamente a malha urbana do país (o cultivo da cana-de-açúcar, no século XVI, possibilitou o desenvolvimento das cidades de Salvador e Recife; o ciclo do Ouro, século XVIII, foi a mola propulsora para a implantação de núcleos urbanos nas Minas Gerais, em São Paulo e, posteriormente, nas regiões de Mato Grosso e Goiás; o ciclo do café, passando a dominar a economia, deslocou o eixo populacional para o sul do país, fazendo com que São Paulo, Rio de Janeiro e Minas Gerais absorvessem mão de obra escrava

32 PRADO JÚNIOR, Caio. História econômica do Brasil. São Paulo: Círculo do Livro, 1988, p. 84. 
vinda do Nordeste assim como a de imigrantes europeus, causando um inchaço em seus núcleos populacionais devido à sua ocupação desenfreada. A adoção de uma política econômica baseada principalmente na exportação propiciou a formação e desenvolvimento das cidades litorâneas, pois estas representavam, na época, entrepostos comerciais que serviam aos propósitos da economia agrícola e escravagista, levando ao implemento da população urbana, principalmente a partir de 1872$)^{33}$.

A falta de preocupação com o vertiginoso crescimento das cidades, aliada a ausência de planejamento, gerou o quadro anteriormente ilustrado no qual um aglomerado de pessoas vive à margem da sociedade e onde impera a violência, poluição, marginalidade e o tráfico caótico, mais conhecido como favelas, afetando diretamente o meio ambiente da localidade. Conforme leciona Maluf $\left(2010^{34}\right)$, o planejamento e organização das cidades não eram preocupações dos legisladores portugueses e brasileiros. Nesse sentido:

O planejamento e a organização das cidades não estavam elencados entre os problemas mais urgentes dos legisladores portugueses e brasileiros até meados de 1930, quando enfim teve início o processo de industrialização e, consequentemente, iniciou-se a urbanização brasileira. Assim, os interesses do legislador voltaram-se para as cidades, para em 1937 o Decreto-lei $n^{\circ} 58$ referir-se à propriedade urbana pela primeira vez

${ }^{33}$ MALUF, Adriana Caldas do Rego Freitas Dabus. Limitações ao direito de propriedade - ob. cit., 2010, p. 65-66.

34 MALUF, Adriana Caldas do Rego Freitas Dabus. Limitações ao direito de propriedade - ob. cit., 2010, p. 66. (procurando trazer segurança às transações imobiliárias, uma vez que regulava o parcelamento do solo) ${ }^{35}$.

O descuido com a organização das cidades, acrescido ao entendimento de que elas eram sinônimos de avanço e modernidade, complicava ainda mais a sua organização, uma vez que a falta de políticas públicas de crescimento organizado e o êxodo de pessoas do campo, para as metrópoles na busca de oportunidades, contribuía para a formação das favelas e a concentração de pessoas em locais onde não havia a menor segurança jurídica e as regras eram criadas ao bel prazer dos que controlavam esses setores, invariavelmente traficantes.

Somente com a Constituição da República de 1988 (CR/88), em seus arts. $182^{36}$ e $183^{37}$, teve início uma política voltada

\footnotetext{
35 MALUF, Adriana Caldas do Rego Freitas Dabus. Limitações ao direito de propriedade - ob. cit., 2010, p. 66.

${ }^{36}$ Art. 182 da CR/88. A política de desenvolvimento urbano, executada pelo Poder Público municipal, conforme diretrizes gerais fixadas em lei, tem por objetivo ordenar o pleno desenvolvimento das funções sociais da cidade e garantir o bem-estar de seus habitantes.

$\S 1^{\circ}$ - O plano diretor, aprovado pela Câmara Municipal, obrigatório para cidades com mais de vinte mil habitantes, é o instrumento básico da política de desenvolvimento e de expansão urbana.

$\S 2^{\circ}$ - A propriedade urbana cumpre sua função social quando atende às exigências fundamentais de ordenação da cidade expressas no plano diretor.

$\S 3^{\circ}$ - As desapropriações de imóveis urbanos serão feitas com prévia e justa indenização em dinheiro.

$\S 4^{\circ}$ - É facultado ao Poder Público municipal, mediante lei específica para área incluída no plano diretor, exigir, nos termos da lei federal, do proprietário do solo urbano não edificado, subutilizado ou não utilizado, que promova seu adequado aproveitamento, sob pena, sucessivamente, de:

I - parcelamento ou edificação compulsórios;

II - imposto sobre a propriedade predial e territorial urbana progressivo no tempo;
} 
para a urbanização brasileira. Nos dispositivos em comento percebe-se a preocupação com a produção de normas sobre a propriedade imóvel, valorizando sua função social e adequação da sua utilização às atividades urbanas em prol do benefício da coletividade.

Nesse novo ambiente de maior importância organizacional das cidades, o plano diretor definido no $\S 1^{\circ}$, do art. 182 da $\mathrm{CR} / 88$ recebe a função de ser o instrumento básico de política de desenvolvimento $\mathrm{e}$ expansão urbana, a fim de garantir o bem estar dos habitantes. Em 2001, a Lei $n^{0}$ 10.257, Estatuto da Cidade, regulamentou os arts. 182 e 183 da CR/88 estabelecendo diretrizes para a política urbana, definindo como sendo a função social das cidades o fornecimento de habitação, trabalho, circulação e lazer. Em conformidade com Maluf (2010), tais funções visam a plena integração dos seres humanos, seu crescimento educacional e cultural, num

III - desapropriação com pagamento mediante títulos da dívida pública de emissão previamente aprovada pelo Senado Federal, com prazo de resgate de até dez anos, em parcelas anuais, iguais e sucessivas, assegurados o valor real da indenização e os juros legais (BRASIL, 1988).

${ }^{37}$ Art. 183 da CR/88. Aquele que possuir como sua área urbana de até duzentos e cinquenta metros quadrados, por cinco anos, ininterruptamente e sem oposição, utilizando-a para sua moradia ou de sua família, adquirir-lhe-á o domínio, desde que não seja proprietário de outro imóvel urbano ou rural.

$\S 1^{\circ}$ - O título de domínio e a concessão de uso serão conferidos ao homem ou à mulher, ou a ambos, independentemente do estado civil.

$\S 2^{\circ}$ - Esse direito não será reconhecido ao mesmo possuidor mais de uma vez.

$\S 3^{\circ}$ - Os imóveis públicos não serão adquiridos por usucapião (BRASIL, 1988). ambiente sustentável e ecologicamente equilibrado.

Ao contrário da evolução desorganizada de outrora, agora as regras constitucionais dão diretrizes claras de como deve se dar a expansão das cidades, devendo ser observados critérios de edificação, utilização do imóvel, dentre outros, com a finalidade de beneficiar a sociedade em geral, cuja inobservância sujeitam os seus proprietários a infrações administrativas que podem em um limite extremo chegar à expropriação do bem.

Essas restrições impostas à propriedade não têm a intenção de impedir o crescimento e desenvolvimento das urbes, mas sim de fazer com que elas cresçam de forma sustentável. Como explica Maluf (2010):

No novo panorama legislativo, definem-se as cidades sustentáveis como aquelas que se desenvolvem de forma coesa, ordenada, sem degradação, possibilitando uma vida urbana digna para todos. Para que o administrador público possa exercer de maneira eficaz os programas previamente estabelecidos de ordenação das cidades, utilizam-se os instrumentos urbanísticos, possibilitando que a cidade cumpra a sua função principal, como estabelece o artigo 182, § $4^{\circ}$, da Constituição Federal $^{38}$.

Portanto, mais que limites ou restrições ao direito de propriedade, a função social cria condições para que haja

\footnotetext{
${ }^{38}$ MALUF, Adriana Caldas do Rego Freitas Dabus. Limitações ao direito de propriedade - ob. cit., 2010, p. 69.
} 
desenvolvimento social e econômico, preservando o meio ambiente, de forma que gere vantagens a todos. Por óbvio, não se pode deixar de analisar a função social e as limitações ao direito de propriedade urbana, uma vez que nos dias atuais falar em domínio necessariamente está a se referir principalmente ao espaço urbano onde se concentra a maioria da população e onde o uso incorreto da propriedade afeta diretamente aos demais integrantes das cidades.

No tocante ao direito de propriedade urbana, suas limitações são impostas via leis especiais que tem o propósito de proteger o interesse público e o privado $^{39}$, não podendo afetar a extensão do exercício do direito de propriedade, citando como exemplo servidões, limitações ao parcelamento do solo urbano e das relações de vizinhança.

O desenvolvimento das cidades, portanto, vincula-se obrigatoriamente ao desenvolvimento sustentável, de políticas urbanas que garantam a preservação do meio ambiente e considerem os aspectos naturais e culturais do local. Em outras palavras, pressupõe o cumprimento da função socioambiental, nos termos das lições de Dorneles $\left(2011^{40}\right)$.

As restrições à propriedade acabam por criar a ideia de que existe uma

\footnotetext{
39 Interesse particular considerado em função da necessidade social de coexistência pacífica.

40 DORNELES, Ana Clara Bertoglio. A função socioambiental da propriedade e a propriedade privada - ob. cit., 2011, p. 297.
}

subordinação do direito de propriedade privada em prol dos interesses públicos, muito embora atinjam a liberdade do proprietário de usar o bem da forma que lhe convier. São de suma importância, pois criam um ambiente de bem estar coletivo, gerando segurança econômica no país, como afirma Maluf $\left(2010^{41}\right)$. Mais além disso, ela (2010) destaca que o Estado interfere sim no exercício da propriedade, mas com um objetivo maior de assegurar normas de cunho social como salubridade, segurança, conforto urbano, imposição de áreas livres e espaços verdes, todos característicos da função social da propriedade urbana.

É notório que essas regras existem para estabelecer o limite da propriedade, não havendo, portanto, a concepção absoluta do direito de propriedade tal qual no Direito romano, tendo atualmente uma sobreposição do interesse público sobre o particular. $\mathrm{O}$ Estado deve intervir de modo a fazer com que cada um usufrua do seu direito, sem que isso se constitua em um prejuízo a outrem e, para isso, vale-se das limitações urbanas legais dispostas ao longo do Código Civil (CC/2002), como, por exemplo, os §§ do art. $1.228^{42}$, que abriga as formas de uso da

${ }^{41}$ MALUF, Adriana Caldas do Rego Freitas Dabus. Limitações ao direito de propriedade - ob. cit., 2010, p. 112.

42 Art. 1.228 do $\mathrm{CC} / 2002$. O proprietário tem a faculdade de usar, gozar e dispor da coisa, e o direito de reavê-la do poder de quem quer que injustamente a possua ou detenha.

$\S 1^{\underline{o}} \mathrm{O}$ direito de propriedade deve ser exercido em consonância com as suas finalidades econômicas e sociais e de modo que sejam preservados, de 
propriedade ou o art. $1.230^{43}$, que dispõe sobre limitação ao direito de propriedade do uso do solo, não abrangendo esse as jazidas, minas e demais recursos minerais.

A densidade populacional e a complexa convivência entre os habitantes fazem surgir a cada dia que passa novas situações que vão fazer o Estado editar normas para regulá-las. Por exemplo, na busca de solução para moradia devido ao adensamento urbano surgem as construções verticais e com elas um novo tipo de convívio social, que é regulado pelo direito de vizinhança, no qual o direito do proprietário é claramente atingido com limitações, isto é, deveres de abstenção de certos usos da coisa

conformidade com o estabelecido em lei especial, a flora, a fauna, as belezas naturais, o equilíbrio ecológico e o patrimônio histórico e artístico, bem como evitada a poluição do ar e das águas.

$\S 2^{\underline{Q}}$ São defesos os atos que não trazem ao proprietário qualquer comodidade, ou utilidade, e sejam animados pela intenção de prejudicar outrem.

$\S 3^{\circ} \mathrm{O}$ proprietário pode ser privado da coisa, nos casos de desapropriação, por necessidade ou utilidade pública ou interesse social, bem como no de requisição, em caso de perigo público iminente.

$\S 4^{\circ} \mathrm{O}$ proprietário também pode ser privado da coisa se o imóvel reivindicado consistir em extensa área, na posse ininterrupta e de boa-fé, por mais de cinco anos, de considerável número de pessoas, e estas nela houverem realizado, em conjunto ou separadamente, obras e serviços considerados pelo juiz de interesse social e econômico relevante.

$\S 5^{\mathrm{O}}$ No caso do parágrafo antecedente, o juiz fixará a justa indenização devida ao proprietário; pago o preço, valerá a sentença como título para o registro do imóvel em nome dos possuidores (BRASIL, 2002).

${ }^{43}$ Art. 1.230 do CC/2002. A propriedade do solo não abrange as jazidas, minas e demais recursos minerais, os potenciais de energia hidráulica, os monumentos arqueológicos e outros bens referidos por leis especiais. Parágrafo único. O proprietário do solo tem o direito de explorar os recursos minerais de emprego imediato na construção civil, desde que não submetidos a transformação industrial, obedecido o disposto em lei especial (BRASIL, 2002). própria ou até mesmo de tolerância de utilização por outrem.

\section{O DESENVOLVIMENTO DOS CENTROS URBANOS, DA PROPRIEDADE PRIVADA E OS IMPACTOS AO MEIO AMBIENTE}

Conforme demonstrado ao longo do presente trabalho, as sociedades cresceram e se desenvolveram econômica e tecnologicamente de forma muito rápida e a velocidade desse crescimento gerou violentos impactos ao meio ambiente. Não raro é ver notícias de desastres ecológicos, desmatamentos criminosos em prol da expansão imobiliária.

Não se pode impedir o crescimento e desenvolvimento das cidades. À medida que se percebe os grandes impactos ao meio ambiente e a elevação do nível de degradação dos centros urbanos, torna-se crescente a preocupação com sua proteção e valorização, pois é sabido que não há condições de vida sem que haja harmonização entre sociedade, desenvolvimento econômico, industrial e a preservação do meio ambiente.

Quando se fala em meio ambiente, há que se ter em mente três espécies, conforme leciona Maluf (2010): meio ambiente natural, formado por solo, água, ar, flora e fauna; meio ambiente cultural, constituído pelo patrimônio histórico, artístico e cultural; e o meio ambiente artificial, construído pelo homem e composto pelos edifícios, 
equipamentos urbanos, comunitários e demais

assentamentos de reflexos urbanos.

\section{Cada um desses diferentes tipos possui}

no ordenamento jurídico pátrio um conjunto

de leis para sua proteção, organização e condições de desenvolvimento, para que não prejudiquem a vida nos centros urbanos e a sociedade em geral. Assim, o meio ambiente natural encontra respaldo constitucional no art. $225, \S 1^{\circ}$, incisos I ao VII, da CR/88 $8^{44}$.

${ }^{44}$ Art. 225 da CR/88. Todos têm direito ao meio ambiente ecologicamente equilibrado, bem de uso comum do povo e essencial à sadia qualidade de vida, impondo-se ao Poder Público e à coletividade o dever de defendê-lo e preservá- lo para as presentes e futuras gerações.

$\S 1^{\circ}$ - Para assegurar a efetividade desse direito, incumbe ao Poder Público:

I - preservar e restaurar os processos ecológicos essenciais e prover o manejo ecológico das espécies e ecossistemas;

II - preservar a diversidade e a integridade do patrimônio genético do País e fiscalizar as entidades dedicadas à pesquisa e manipulação de material genético;

III - definir, em todas as unidades da Federação, espaços territoriais e seus componentes a serem especialmente protegidos, sendo a alteração e a supressão permitidas somente através de lei, vedada qualquer utilização que comprometa a integridade dos atributos que justifiquem sua proteção;

IV - exigir, na forma da lei, para instalação de obra ou atividade potencialmente causadora de significativa degradação do meio ambiente, estudo prévio de impacto ambiental, a que se dará publicidade;

V - controlar a produção, a comercialização e o emprego de técnicas, métodos e substâncias que comportem risco para a vida, a qualidade de vida e o meio ambiente;

VI - promover a educação ambiental em todos os níveis de ensino e a conscientização pública para a preservação do meio ambiente;

VII - proteger a fauna e a flora, vedadas, na forma da lei, as práticas que coloquem em risco sua função ecológica, provoquem a extinção de espécies ou submetam os animais a crueldade.

$\S 2^{\circ}$ - Aquele que explorar recursos minerais fica obrigado a recuperar o meio ambiente degradado, de acordo com solução técnica exigida pelo órgão público competente, na forma da lei.

$\S 3^{\circ}$ - As condutas e atividades consideradas lesivas ao meio ambiente sujeitarão os infratores, pessoas físicas
Por sua vez, o art. 216 do mesmo diploma ${ }^{45}$ refere-se ao ambiente cultural e, por fim, o

ou jurídicas, a sanções penais e administrativas, independentemente da obrigação de reparar os danos causados.

$\S 4^{\circ}$ - A Floresta Amazônica brasileira, a Mata Atlântica, a Serra do Mar, o Pantanal Mato-Grossense e a Zona Costeira são patrimônio nacional, e sua utilização far-se-á, na forma da lei, dentro de condições que assegurem a preservação do meio ambiente, inclusive quanto ao uso dos recursos naturais.

$\S 5^{\circ}$ - São indisponíveis as terras devolutas ou arrecadadas pelos Estados, por ações discriminatórias, necessárias à proteção dos ecossistemas naturais.

$\S 6^{\circ}$ - As usinas que operem com reator nuclear deverão ter sua localização definida em lei federal, sem o que não poderão ser instaladas (BRASIL, 1988).

45 Art. 216 da CR/88. Constituem patrimônio cultural brasileiro os bens de natureza material e imaterial, tomados individualmente ou em conjunto, portadores de referência à identidade, à ação, à memória dos diferentes grupos formadores da sociedade brasileira, nos quais se incluem:

I - as formas de expressão;

II - os modos de criar, fazer e viver;

III - as criações científicas, artísticas e tecnológicas;

IV - as obras, objetos, documentos, edificações e demais espaços destinados às manifestações artísticoculturais;

V - os conjuntos urbanos e sítios de valor histórico, paisagístico, artístico, arqueológico, paleontológico, ecológico e científico.

$\S 1^{\circ}$ - O Poder Público, com a colaboração da comunidade, promoverá e protegerá o patrimônio cultural brasileiro, por meio de inventários, registros, vigilância, tombamento e desapropriação, e de outras formas de acautelamento e preservação.

$\S 2^{\circ}$ - Cabem à administração pública, na forma da lei, a gestão da documentação governamental e as providências para franquear sua consulta a quantos dela necessitem.

$\S 3^{\circ}$ - A lei estabelecerá incentivos para a produção e o conhecimento de bens e valores culturais.

$\S 4^{\circ}$ - Os danos e ameaças ao patrimônio cultural serão punidos, na forma da lei.

$\S 5^{\circ}$ - Ficam tombados todos os documentos e os sítios detentores de reminiscências históricas dos antigos quilombos.

$\S 6^{\circ}$ É facultado aos Estados e ao Distrito Federal vincular a fundo estadual de fomento à cultura até cinco décimos por cento de sua receita tributária líquida, para o financiamento de programas e projetos culturais, vedada a aplicação desses recursos no pagamento de:

I - despesas com pessoal e encargos sociais;

II - serviço da dívida;

III - qualquer outra despesa corrente não vinculada diretamente aos investimentos ou ações apoiados (BRASIL, 1988). 
ambiente artificial está regulado pelos art. $5^{\circ}$, inciso $\mathrm{XXIII}^{46}$, e art. 21, inciso $\mathrm{XX}^{47}$, tratando, respectivamente, da função social da propriedade e das diretrizes para $\mathrm{o}$ desenvolvimento urbano.

Dentre esses três tipos de meio ambiente, o ambiente artificial por ter a característica de ser construído pelo homem acaba por ser o que mais afeta o meio ambiente natural, pois o seu crescimento implica necessariamente em redução das áreas verdes e ocasiona impacto de âmbito geral na vida coletiva.

Preconiza a CR/88 em seu art. 23, inciso VI, que União, Estados e Municípios têm competência comum para proteger o meio ambiente e combater a poluição em todas as suas formas. O CC/2002 também se preocupou em dar proteção ao meio ambiente, no já mencionado $\S 1^{\circ}$, do 1.228 .

Farias e Rosenvald $\left(2012^{48}\right)$ destacam que o citado art. 1228 do CC, em seu $\S 1^{\circ}$, tem o propósito de harmonizar a propriedade privada a princípios correlatos aos interesses difusos, em especial, o meio ambiente, que,

\footnotetext{
${ }^{46}$ Art. $5^{\circ}$ da CR/88. Todos são iguais perante a lei, sem distinção de qualquer natureza, garantindo-se aos brasileiros e aos estrangeiros residentes no País a inviolabilidade do direito à vida, à liberdade, à igualdade, à segurança e à propriedade, nos termos seguintes: XXIII - a propriedade atenderá a sua função social (BRASIL, 1988).

47 Art. 21 da CR/88. Compete à União: XX - instituir diretrizes para o desenvolvimento urbano, inclusive habitação, saneamento básico e transportes urbanos (BRASIL, 1988).

48 FARIAS, Cristiano Chaves de; ROSENVALD, Nelson. Curso de direito civil: direitos reais. 8. ed. Salvador: JusPodivm, 2012. v. 5, p. 335.
}

em regra, terá prevalência sobre interesses econômicos.

É clara a preocupação do legislador com a proteção do meio ambiente, tanto que com a CR/88, em seu art. 225, e com a Lei ${ }^{\circ}$ 10.501/01, a cidade passa a ter uma natureza jurídico-ambiental e o plano diretor se configura no instrumento regulador básico da política de desenvolvimento e crescimento urbano, contendo elementos a serem adotados no meio ambiente artificial, a fim de evitar prejuízos ao ambiente natural.

Segundo Farias e Rosenval $\left(2012^{49}\right)$, em seu art. 225, a CR/88 consagrou a função socioambiental do direito de propriedade, de modo a superar a visão individualista herdada no direito brasileiro. E como bem salientam os autores $\left(2012^{50}\right)$, uma propriedade ambientalmente saudável trará benefício à coletividade, uma vez que se constituirá em fator de crescimento econômico e será capaz de promover a redução das desigualdades sociais no país. Leia-se:

O fato de alguém ser proprietário não
lhe outorga um mandato de
exploração irracional dos recursos
naturais da propriedade. Ha um
compromisso de solidariedade pelo
qual o particular e o Estado devem
participar na tutela ambiental,
preservando-a para as gerações
futuras. Os princípios ambientais
avançam para o interior do direito
subjetivo de propriedade, como
supervalor metaindividual que irá
concretamente fundamentar a tensão

49 FARIAS, Cristiano Chaves de; ROSENVALD, Nelson. Curso de direito civil - ob. cit., 2012, p. 336.

50 FARIAS, Cristiano Chaves de; ROSENVALD, Nelson. Curso de direito civil - ob. cit., 2012, p. 336. 
entre as funções individual e social da propriedade $^{51}$.

$\mathrm{O}$ rápido crescimento das urbes e as grandes evoluções tecnológicas que trazem consigo aumento de poluição, degradação do ambiente e das águas, torna necessário a sedimentação de que há a necessidade do uso racional da propriedade e dos meios de produção, tal qual afirma Custódio (1983):

\begin{abstract}
A necessidade do uso racional da propriedade se transformou numa das maiores preocupações do Poder Público, no sentido de intervir no seu exercício, visando atenuar ou evitar os efeitos danosos de um crescimento urbano espontâneo e desordenado, prejudicial à qualidade de vida ${ }^{52}$.
\end{abstract}

A proteção ao meio ambiente natural tem como pano de fundo o uso racional da propriedade e podem ser utilizadas medidas legais e judiciais rigorosas, que tornem possível um planejamento adequado para controlar ou minimizar os impactos das construções, restringindo, em prol do interesse coletivo, o direito de construir, usar, gozar e dispor dos imóveis citadinos.

É óbvio que não há como impedir o crescimento das cidades, mas há que se preocupar em que haja um crescimento sustentável, onde possa existir o conceito de

51 FARIAS, Cristiano Chaves de; ROSENVALD, Nelson. Curso de direito civil - ob. cit., 2012, p. 336.

52 CUSTÓDIO, Helita Barreira. Limitações à propriedade revestida de vegetação. Revista de Direito Civil, Imobiliário, Agrário e Empresarial, São Paulo, ano 7, v. 25, p. 95-133, jul./set. 1983, p. 95. Para aprofundamentos, ver CUSTÓDIO, Helita Barreira. Limitações à propriedade revestida de vegetação - ob. cit., 1983, p. 95-97. "cidades sustentáveis". Assim leciona Medauar (2004):

As questões urbana e ambiental encontram-se intimamente ligadas, sendo que o ordenamento dos espaços urbanos aparece como instrumento da política ambiental, uma vez que "a implantação de uma política urbana não pode ignorar a questão ambiental", principalmente nos grandes centros urbanos onde os problemas relativos ao meio ambiente adquirem uma feição maior, como: a questão da poluição (do ar, das águas, sonora, visual), do saneamento básico, a ausência de áreas verdes e sua consequente influência no ser humano ${ }^{53}$.

Os problemas como crescimento populacional e expansão urbana em países como o Brasil, geram de forma clara uma tendência a aglomerados, as chamadas favelas, que se proliferam cada vez mais nas grandes metrópoles. Elas além dos problemas relacionados à violência tão característicos desses bolsões, implicam enormes prejuízos ao meio ambiente, visto que todo o lixo e esgoto de tais localidades não recebem qualquer tipo de tratamento.

Essa expansão desenfreada das cidades e a incapacidade das autoridades em fornecer mínimas condições de saneamento básico, coleta de lixo e tratamento de esgoto na mesma velocidade do crescimento das cidades gera aos ambientalistas grandes preocupações com os recursos hídricos ${ }^{54}$.

53 MEDAUAR, Odete. Estatuto da Cidade: comentários. 2. ed. São Paulo: Revista dos Tribunais, 2004, p. 25.

${ }^{54}$ É sabido que o Estado de São Paulo vive nos dias de hoje uma das maiores crises hídricas de sua história 
Sempre considerada como fonte inesgotável, a água, hoje, é vista como a principal preocupação, não só dos ambientalistas, mas de toda a sociedade. $\mathrm{O}$ atual período de seca no Brasil nunca foi tão severo e mostrou que, acima de tudo, a atenção com o meio ambiente passa inexoravelmente pela proteção das águas e dos mananciais, pois o meio ambiente é um complexo formado por várias partes em que se tem a água como um dos bens mais importantes.

Preocupados com os problemas advindos do desenvolvimento econômico, hoje existem diversas leis que, além de impor limitações ao direito de propriedade, também voltam-se à penalização dos responsáveis por prejuízos causados ao meio ambiente. Como afirma Silva (2000):

(VENCESLAU, Pedro; LEITE, Fabio. Seca atual só ocorre a cada 3.378 anos. Estado de São Paulo, São Paulo-SP, 13 mai. 2014, internet). Esta crise importa em sofrimento a milhares de cidadãos, colocando em xeque a qualidade de vida de outros tantos. Ao margear todo esse drama humano, tem-se que no campo econômico os prejuízos da maior seca no Estado de São Paulo já são alarmantes. No setor de agronegócio, o transporte de soja por rodovia, após a paralisação da Hidrovia Tietê/Paraná, já custou R\$ 30 milhões ou mais aos produtores. A cidade de Tambaú, polo da indústria cerâmica, está amargando um prejuízo de $\mathrm{R} \$$ 4 milhões com a queda da produção pela escassez de água; grandes empresas, como a JBS, localizada em Barretos, a $440 \mathrm{~km}$ da Capital paulista, anteciparam as férias coletivas e paralisaram a produção após a prefeitura decretar o racionamento. Em Guarulhos, na Grande São Paulo, a fabricante de motores Cummins compra todos os dias seis carros-pipa para evitar que a produção pare (sendo que cada caminhão custa em média R\$ 1 mil) (SORIMA NETO, João; SCRIVANO, Roberta. Seca já gera perdas à indústria paulista. $O$ Globo, São Paulo-SP, 29 out. 2014, internet). a definição do modelo de assentamento urbano permite a intervenção da municipalidade no sentido de impor às construções tipos adequados à paisagem urbana. Constituem partes integrantes dos projetos urbanos a implantação de parques e jardins, padronização estéticas das construções, onde a fachada constitui importante elemento da paisagem, influenciandoa com a harmonia dos seus traços, elementos de iluminação, sinalização e publicidade ${ }^{55}$.

Como visto, o crescimento urbano e das cidades afeta diretamente o meio ambiente. Assim, é claro que o meio ambiente $\operatorname{artificial}^{56}$, se não for edificado de forma sustentável comprometerá diretamente o meio ambiente natural e a sociedade como um todo. Para prevenir essas interferências é que são criados instrumentos reguladores do ambiente artificial. A título de exemplo tem-se o Estudo de Impacto de Vizinhança (EIV), meio de política urbana que tem fundamental importância na confecção dos espaços habitáveis.

Há também previsões normativas no sentido de punir com multas, perda de patrimônio e recomposição de espaços, os responsáveis por danos ecológicos causados ao meio ambiente. O já citado art. $225, \S 3^{\circ}$, da $\mathrm{CR} / 88$ previu que as condutas e atividades consideradas lesivas ao meio ambiente, sujeitarão os infratores, pessoas físicas ou jurídicas, a sanções penais e administrativas, independentemente da obrigação de reparar os

55 SILVA, José Afonso da. Direito urbanístico brasileiro. 3. ed. São Paulo: Malheiros, 2000, p. 292293. 
danos causados. As referidas multas serão objeto de posterior estudo.

Sem embargo, tal previsão constitucional e a existência de instrumentos que intimidem as agressões ao meio ambiente, certamente são uma evolução grande no sentido de proteção, mas o dilema é que apesar de estarem previstas tais sanções, os danos ecológicos causados demandam muitos anos para serem recompostos, devido ao tempo de recuperação da natureza ser muito lento. Isso revela que as punições aos infratores são essenciais, mas, mais que isso, é de extrema relevância uma política de prevenção a desastres ecológicos.

Como afirma Maluf (2010), a proteção ao meio ambiente deve ter um caráter preventivo muito mais do que reparatório. Dessa forma:

\begin{abstract}
A proteção do meio ambiente deve apresentar um caráter preventivo mais do que reparatório, uma vez que os danos causados em matéria ambiental são em geral irreversíveis ou de difícil reparação, visto que estão envolvidos muitas vezes ecossistemas completos que demoram muito tempo para se desenvolver, e a natureza possui um ritmo próprio de regeneração, que pode ser fatal para as espécies circundantes quando do uso inapropriado do meio ambiente pelo homem $^{57}$.
\end{abstract}

Face ao exposto, resta claro que o crescimento econômico tanto quanto o desenvolvimento das cidades devem ser feitos

\footnotetext{
57 MALUF, Adriana Caldas do Rego Freitas Dabus. Limitações ao direito de propriedade - ob. cit., 2010, p. 253.
}

de modo sustentável, a fim de que possa ser harmonizada a relação de convívio entre os cidadãos, suas necessidades de moradia e de trabalho, tendo como meta principal o respeito ao meio ambiente e aos recursos naturais, observando-se que a existência de um depende intimamente do outro.

\section{CONSIDERAÇÕES FINAIS}

Ao final do exposto, ainda não se vê de forma clara uma definição precisa para a função social do direito de propriedade. Constata-se que há uma convergência no sentido de entender que seu significado seja dinâmico, pois sua definição se dará de acordo com o período histórico, meio social e pretensões econômicas em que estiver inserida.

A cada época da história o sentido dado ao direito de propriedade e sua função é cunhado tendo como base os valores, as relações sociais e o ponto de avanço que a sociedade apresenta. Em sociedades ainda pouco desenvolvidas e com menores interações entre seus indivíduos, os problemas sociais causados pelo mau uso da propriedade são menos significativos, o que minimiza sua importância. Em sentido oposto, em sociedades mais atuais e complexas, com grande adensamento populacional, o mau uso do domínio interfere diretamente no cotidiano e nos direitos dos demais, o que leva ao Estado a criar regras para a sua utilização, objetivando o bem estar coletivo. 
Por sua vez, a função social funciona como limitador e organizador do uso da propriedade, de forma a alcançar uma situação melhor para todos ou, pelo menos, para a maior parte de um grupo social, ainda que para isso seja necessário colocar o direito coletivo acima do individual.

Essa característica metamórfica do direito de propriedade lhe confere interpretações, visões e graus de importância específicos, principalmente quando se estuda a sua função social analisada sob a ótica de diferentes nações.

Nesse contexto, quando se analisa a função social da propriedade em países da Europa, onde há uma grande valorização da cultura, percebe-se que os limites por ela impostos abarcam, por exemplo, a proteção ao patrimônio histórico e cultural. Tal fato leva a percepção de que tanto o direito de propriedade quanto a função social são formados levando-se em conta os valores de cada Estado.

Por outro lado, no Brasil onde a propriedade foi fortemente marcada pelo tipo de colonização, a terra foi "distribuída" de acordo com a conveniência do colonizador e criou-se na população uma visão distorcida da propriedade privada, de modo que, ao invés ser vista como um mecanismo que produzirá melhores condições de vida, passa a ser tratada como um privilégio de uma minoria detentora de maiores recursos financeiros. Esquece-se, portanto, que com a propriedade há que suportar também um ônus inerente a ela e que muitos talvez não sejam capazes de arcar com eles.

Além disso, a situação se agrava ainda mais em um país com uma distribuição de renda tão desigual, impedindo que se consiga ver que não é necessário "ser dono" para ter uma vida digna e confortável. Na medida em que a propriedade cumpre a sua função, certamente existirá um ambiente favorável a produzir melhor condição social com aumento dos postos de emprego e diminuição da disparidade social brasileira, além de efetivar melhoria na situação de vida em geral com a preservação e conservação do meio ambiente.

De maneira que no tocante as limitações impostas à propriedade urbana e que afetam de forma mais direta o direito do proprietário, estabelecendo regras de qual espaço usar, quanto usar e como fazer, emerge-se novamente o importante papel da função social, ou melhor, da função socioambiental do domínio.

É um contrassenso impedir o desenvolvimento dos meios urbanos. Todavia, ele deve ser pautado em crescimento sustentável. Com isso, será possível aliar crescimento, desenvolvimento e, ao mesmo tempo, preservação do meio ambiente, em todos os seus âmbitos, o que é o mínimo para que se alcance melhores condições de vida hoje e para as décadas que virão, isto é, para as futuras gerações. 


\section{REFERÊNCIAS}

ALVIM, Rui Carlos Machado. Análise das concepções romanas da propriedade e das obrigações: reflexos no mundo moderno. Revista de Direito Civil, Imobiliário, Agrário e Empresarial, São Paulo, ano 4, v. 12, p. 25-38, abr./jun. 1980.

BRASIL. Código Civil; Comercial; Processo Civil e Constituição Federal. Obra coletiva de autoria da Editora Saraiva com a colaboração de Luiz Roberto Curia, Lívia Céspedes e Juliana Nicoletti. 8. ed. São Paulo: Saraiva, 2012.

COULANGES, Fustel de. A cidade antiga. São Paulo: Martins Fontes, 2000.

CUSTÓDIO, Helita Barreira. Limitações à propriedade revestida de vegetação. Revista de Direito Civil, Imobiliário, Agrário e

Empresarial, São Paulo, ano 7, v. 25, p. 95-133, jul./set. 1983.

DEL NERO, João Alberto Schutzer. O significado jurídico da expressão "função social da propriedade". Revista da Faculdade de Direito de São Bernardo do Campo, São Bernardo do Campo, v. 3, p. 79-97, 1997.

DORNELES, Ana Clara Bertoglio. A função socioambiental da propriedade e a propriedade privada. Revista de Direito Ambiental e Sociedade, Caxias do Sul, v. 1, nº 1, p. 273-300, jan./jun. 2011.

FACHIN, Luiz Edson. Da propriedade como conceito jurídico. Revista dos Tribunais, São Paulo, v. 76, nº 621, p. 16-39, jul. 1987.

FARIAS, Cristiano Chaves de; ROSENVALD, Nelson. Curso de direito civil: direitos reais. 8. ed. Salvador: JusPodivm, 2012. v. 5.

GIORDANI, Jose Acir Lessa. Propriedade imóvel: seu conceito, sua garantia e sua função social na nova ordem constitucional. Revista dos Tribunais, São Paulo, v. 80, nº 669, p. 4756, jul. 1991.
GOITIA, Fernando Chueca. Breve história do urbanismo. Tradução por Emílio Campos Lima. 5. ed. Lisboa: Editorial Presença, 2003.

MALUF, Adriana Caldas do Rego Freitas Dabus. Limitações ao direito de propriedade. São Paulo: Atlas, 2010.

MEDAUAR, Odete. Estatuto da Cidade: comentários. 2. ed. São Paulo: Revista dos Tribunais, 2004.

PEREIRA, Caio Mário da Silva. Condomínio e incorporações. 7. ed. Rio de Janeiro: Forense, 1993.

PRADO JÚNIOR, Caio. História econômica do Brasil. São Paulo: Círculo do Livro, 1988.

ROSENFIELD, Denis Lerrer. Reflexões sobre o direito à propriedade. Rio de Janeiro: Editora: Campus Jurídico, 2008.

SCIALOJA, Vittorio. Teoria della proprieta, lezioni ordinate, curate. Roma: Edite da Pietro Bonfante, 1933. v. II.

SILVA, José Afonso da. Direito urbanístico brasileiro. 3. ed. São Paulo: Malheiros, 2000.

SORIMA NETO, João; SCRIVANO, Roberta. Seca já gera perdas à indústria paulista. $O$ Globo, São Paulo-SP, 29 out. 2014. Disponível em:

<http://aarffsa.com.br/noticiasnovas/noticia_29 10201429.pdf>. Acesso em: 06 jan. 2015.

TIGAR, M.; Levy M. O direito e a ascensão do capitalismo. Rio de Janeiro: Zahar Editores, 1978.

VENCESLAU, Pedro; LEITE, Fabio. Seca atual só ocorre a cada 3.378 anos. Estado de São Paulo, São Paulo-SP, 13 mai. 2014.

Disponível em: <http://saopaulo.estadao.com.br/noticias/geral,seca-atualso-ocorre-a-cada-3378-anos, 1165826>. Acesso em: 27 out. 2014.

ZEA, Arturo Valenciano. Derecho civil. 4. ed. Bogotá: Temis, 1973. 